\title{
Histopathological Effects and Micronucleus Assay of Glyphosate-Based Herbicides on Cultured African Catfish (Clarias Gariepinus, Burchell 1822)
}

Selim Adewale Alarape ( $\square$ link2sas@yahoo.co.uk)

University of Ibadan Faculty of Veterinary Medicine https://orcid.org/0000-0003-1685-2139

Oyindamola Emmanuel Adebiyi

University of Ibadan Faculty of Veterinary Medicine

Olanike Kudirat Adeyemo

University of Ibadan Faculty of Veterinary Medicine

\section{Research}

Keywords: Glyphosate-based herbicides, Clarias gariepinus, Organotoxicity, Genotoxicity, Ecosystem

Posted Date: September 28th, 2021

DOl: https://doi.org/10.21203/rs.3.rs-898459/v1

License: (1) (i) This work is licensed under a Creative Commons Attribution 4.0 International License.

Read Full License 


\section{Abstract}

Background: Glyphosate, a brand of agricultural herbicides which intensive use has led to widespread contamination of different ecosystems. This study was designed to determine both organotoxicity and genotoxicity of glyphosate on African Catfish (Clarias gariepinus) exposed to different concentrations for 96 hours.

Methods: Questionnaires were administered (physically and online) to determine the type of glyphosatebased herbicides mostly used by fish farmers. Seventy-five apparently healthy adult Clarias gariepinus $(300 \mathrm{~g})$ were sourced from a local farmer, transported in a plastic keg to Fish and Wildlife Laboratory at the Department of Veterinary Public Health and Preventive medicine for two (2) weeks of acclimatization. After acclimatization, they were further divided into four (4) groups (T0 (Control), T1 $(0.003 \mathrm{ml} / \mathrm{L}), \mathrm{T} 2$ $(0.0045 \mathrm{ml} / \mathrm{L})$ and T3 $(0.006 \mathrm{ml} / \mathrm{L}))$ by simple randomization and each group replicated into three (3) treatments. At the expiration of 96 hours of exposure, blood samples and organs (Gills, Kidney, and Liver) were collected for mononuclear assay and histopathological lesions respectively.

Results: Exposed groups showed erratic swimming, splashing, and restlessness. Mortalities rate was dose-dependent (two (2) mortalities at $0.0045 \mathrm{ml} / \mathrm{L}$ concentration (T2) and five (5) mortalities $0.006 \mathrm{ml} / \mathrm{L}$ concentration (T3)). Observed histopathological lesions occurred at higher dose treatment $(0.0045 \mathrm{ml} / \mathrm{L}$ (T2) and ( $0.006 \mathrm{ml} / \mathrm{L}) \mathrm{T} 3)$ ) concentrations. The gills showed diffuse stunted and eroded secondary lamellae and severe congestion of the blood channel at the core of the primary lamellae. Lesions in the Liver include severe diffuse vacuolation of the hepatocytes, moderate to severe portal congestion and mild diffuse vacuolation of hepatocytes and moderate diffuse vacuolation of hepatocytes, and severe portal congestion. In the kidney, there was mild to moderate congestion of the interstitium and focus of interstitial oedema within the parenchyma. There was presence of micronucleus in the fish nucleated red blood cells at higher dose concentrations.

Conclusion: This study showed that Glyphosate-based herbicides are highly toxic to Clarias gariepinus, therefore their use near the fish farm or in areas close to the aquatic environment should be discouraged. The agricultural community should also be conscious of the potentially adverse effects of pesticides. This is to prevent the water body from the residue of herbicides that would have washed down to the water.

\section{Introduction}

According to Decline [1], fish production of a pond is the amount of fish gained at harvest and is dependent on the farmer's management and system of practice. Aquaculture practice is the adoption of innovations in fish farming in an enclosure. The degree of aquaculture practices affects productivity, income, and subsequent development. By implication, the type of production practice adopted indicates the level of technology input to stimulate production growth and sustainability. The sustainability of 
aquaculture practice depends on the economic disposition and value it adds to the welfare of the farmer [1].

With the rise in fish farming and aquaculture, there has been an exponential increase in the use of agrochemicals or agrichemical. Agrochemicals refer to pesticides including insecticides, herbicides, and fungicides. Such agrochemicals are marketed as harmless, with little or no side effects by the manufacturers. Despite the rapidly increasing use of these agrochemicals, researchers have viewed some of the chemicals as materials whose environmental fate is poorly understood [3].

The use of agrochemicals, such as herbicides in farming and fish farming, most especially around ponds has raised a lot of questions as regards public health. Examples of chemicals with negative effects on target organisms and public health implications used in aquaculture include Copper sulphate, Malachite green, Formalin, Potassium permanganate, etc. According to Alarape et al., [4], Clarias gariepinus' exposure to copper sulphate resulted in necrotic ovaries, matted lamellae of the gills, and multifocal severe degeneration of the seminiferous tubules while those exposed to Malachite green resulted in disrupted and depleted seminiferous tubules, focal localized vacuolation of skin, and generalized fatty degeneration of liver [5]. The use of agrochemicals can easily be washed into ponds and other water bodies by rain, altering the physiological parameters of the water and the chemicals could also build up in the fishes' systems, and this would pose a threat to human health and public health in general. The herbicide glyphosate (N-phosphonomethyl glycine), is a biocide with a broad-spectrum activity introduced for weed control in agricultural production fields in 1974 [6]. Glyphosate is the active ingredient in the Roundup (Monsanto Company, St. Louis) brand of agricultural herbicides and a variety of other herbicide formulations. These formulations which are used widely in agricultural, forestry, and residential markets provide non-selective, post-emergent control of annual and perennial weeds [7]. Glyphosate is one of the common herbicides used as a non-selective herbicide and for aquatic weed control in fish ponds, lakes, canals, slow running water, which is said to be slightly toxic to mammals and fish [8]. Glyphosate is taken up by the foliage of plants and transported throughout the plant resulting in plant death after several days. Glyphosate is formulated with various adjuvants [9], in particular surfactants such as polyoxyethylene amine (POEA), to enhance the uptake and translocation of the active ingredient in plants. The best-known product formulated with polyoxyethylene amine is Roundup ${ }^{\circledR}[6]$.

Glyphosate is the most extensively used herbicide worldwide. The intensive use of glyphosate has led to its widespread contamination of different ecosystems where it influences plants, microorganisms, animals, and many components of the food chain [10]. Glyphosates are major contaminants of rivers and surface waters [11] as well as organisms, including humans, but also food, feed, and ecosystems [7]. Their use and presence in the food chain are further increased again with more than $75 \%$ of genetically modified edible plants that have been designed to tolerate high levels of these compounds [12], commercialized in various formulations [13].

Glyphosate is one of the widely used herbicides that could be persistent and mobile in soil and water, and it is known to be one of the most common terrestrial and aquatic contaminants [14]. Glyphosate alone is 
not used as an herbicide [15]; in fact, it is always blended with different surfactants to increase its perforation into plant cells which adds to its toxicity [16]. It is used to inhibit weed and clear the space for the growth of vegetation in fields apart from enhancing the plantation in the parks, forests, railway lines, public streets, and gardens.

In the past, glyphosate was considered a nontoxic herbicide because of its low LD50 (the concentration that caused $50 \%$ deaths); $>4 \mathrm{~g} / \mathrm{kg}$ [17]. Ayoola [18] reported that glyphosate toxicity increased with increased concentration. And according to Gill et al., [19], glyphosate's toxicity is not only observed in unicellular organisms but also shows its toxic effects on many multicellular organisms found on both soil and water.

Toxicological effects like genotoxicity, cytotoxicity, nuclear aberration, hormonal disruption, chromosomal aberrations, and DNA damage have also been observed in higher vertebrates like humans [19]. According to Neibor and Richardson [20], the level of toxicity of any pesticide depends on its bioaccumulation, the different chemistries of the compound forming the pesticide, and the reactions of the organisms receiving the toxicant.

\section{Methods}

Fifty pre-tested structured questionnaire asides from online Google forms were distributed to fish farmers to determine the usage of glyphosate chemicals on fish farms as well as the glyphosate brand commonly used. Both Physical and online questionnaire were administered between October, 2019 and January, 2020. Inclusion criteria for the participants include being an active fish farmer irrespective of age, sex, tribe and religion. The recruited participants were from Oyo State and the research work took place at the Fish and Wildlife laboratory, Department of Veterinary Public Health and Preventive Medicine, University of Ibadan, Nigeria.

Seventy-five apparently healthy adult Clarias gariepinus (300g) were sourced from a local farmer. They were transported in a plastic keg to the Fish and Wildlife Laboratory at the Department of Veterinary Public Health and Preventive medicine that same day. The fishes were subsequently transferred into holding tanks for two (2) weeks acclimatization and were fed protein pellets daily at $5 \%$ body weight and later divided into four (4) groups by simple randomization. There were four $\left(T_{1}, T_{2}, T_{3}\right.$ and $\left.T_{0}\right)$ concentrations $(0.15 \mathrm{mls}(0.003 \mathrm{ml} / \mathrm{L}), 0.225 \mathrm{mls}(0.0045 \mathrm{ml} / \mathrm{L})$ and $0.3 \mathrm{mls}(0.006 \mathrm{ml} / \mathrm{L}))$ and a control of $(0 \mathrm{ml})$ respectively and three replicas of each concentration. The chemicals at different concentrations were added to a $50 \mathrm{~L}$ mark tank of water respectively and aerated approximately one hour daily. Physical observation and behavioural changes were observed after the introduction of Force-Up. Water quality parameters were taken using Farmer's test kit (for Alkalinity, pH, Nitrite, and Water hardness), Dissolved Oxygen meter (for Dissolved Oxygen, Temperature, Atmospheric Pressure, and Biochemical Oxygen demand), and Photometer (for ammonia concentration). Fresh solutions were prepared every twenty-four hours while aeration and water quality parameters were repeated daily for five days. 


\section{Sample Collection}

Blood samples were collected from the caudal veins and poured inside EDTA embedded bottles. The fish were euthanized using pithing method while organs (gills, liver, and kidney) were collected through dissection of the fish and placed in plain labeled bottles for histopathology, and preserved with Bouin's fluid for proper tissue preparation and slide production. After tissue sample collection, the fish were deeply buried in the ground and covered up with earth.

\section{Results}

Out of fifty questionnaires administered physically, only thirty (30) were retrieved while there were eight (8) respondents from online Google form. The results of the analysis showed that Catfish farmers have the highest number (Fig. 1) of respondents (25 (65.8\%)), followed by Heterobranchus (7 (18.4\%)) and Hetero-Clarias $(6(15.8 \%))$. Force-Up had the highest usage (13 (18.42\%)), while Vinash had the least 3 (7.89\%) use among the respondents, though $9(23.68 \%)$ of the respondents claimed they were not using herbicides in the control of weeds on the farm. (Fig. 2).

\section{Histopathological Lesions}

There were mortalities at higher treatment concentrations with two (2) mortalities in the second treatment $\left(T_{2}\right)$ and five (5) mortalities in the third treatment $\left(T_{3}\right)$. The observable histopathological lesions mostly occurred at higher dose treatments $\left(T_{2}\right.$ and $\left.T_{3}\right)$ while most of the organs in the lowest dose treatment $\left(T_{1}\right)$ appeared not affected. Histopathological lesions observed showed that livers and kidneys were mostly affected by glyphosate toxicity compared to the gills. Lesions observed in the gills include diffusely stunted and eroded secondary lamellae (Fig. 3) and severe congestion of the blood channel at the core of the primary lamellae (Fig. 4).

In the Liver samples, lesions observed include severe diffuse vacuolation of the hepatocytes at the first treatment concentration (Fig. 5), moderate to severe portal congestion, and mild diffuse vacuolation of hepatocytes at the second treatment concentration (Fig. 6). At the highest treatment dose of $0.3 \mathrm{mls}$, there was moderate diffuse vacuolation of hepatocytes and severe portal congestion (Fig. 7).

The histopathological lesions observed in the kidney include mild to moderate congestion of the interstitium at second treatment concentration (Fig. 8) and focus of interstitial oedema within the parenchyma at third treatment concentration (Fig. 9).

\section{MICRONUCLEUS ASSAY}

Micronucleus assay result revealed normal fish nucleated red blood cells (Fig. 10) at both control and low treatment concentration $(0.15 \mathrm{mls})$ while the higher treatment $(0.225 \mathrm{mls}$ and $0.3 \mathrm{mls})$ concentrations showed micronucleus in the fish nucleated red blood cells (Figs. 11 and 12 respectively). 


\section{Discussion}

Glyphosate is an herbicide that was introduced by Monsanto under the trade name Roundup in 1974 and in the last decade became the most widely used agricultural pesticide worldwide [21]. The above statement was validated by the responses of the respondents in this study where over two-thirds of the respondents $(76.32 \%)$ were using one form of glyphosate or another in the control of weeds on the farm. Though some of the glyphosate products were originally used to control aquatic plants [21] but Fish farmers in Nigeria are using it in the control of weed around the pond and fish farms. Fish in the control experiment were calm and exhibited normal behavioural activities throughout the experimental periods while fish in the treatment groups showed erratic swimming, splashing, restlessness, movement from surface to bottom, sudden movement, and resting at the bottom of the container. The observed behavioural signs were similar to the several reports by Aguigwo, [22], Omoniyi et al., [23], Rahman et al., [24], Okayi et al., [25] and Sani and Idris, [26].

Histopathological lesions observed in collected tissues from the fish were predominantly pronounced in higher dose treatments which are similar to the report of Ayoola, [27] where he reported pronounced lesions at 96 hours exposure with accompanying mortality with an increase in the concentration of the glyphosate. The accompanied mortality pattern observed in this study is also in agreement with the reports of Ayoola, [18] and Sani and Idris, [26]. The observed high mortalities at the highest concentration of the herbicides demonstrated the observation of Fryer, [27] which stated that when a threshold of toxicants is reached, there is no drastic survival of the animal. When below the threshold, an animal will be in a tolerance zone while above the tolerance zone is the zone of resistance.

Observable histopathological lesions showed that livers and kidneys were mostly affected by the glyphosate toxicity compared to the gills which are in agreement with the report of Ayoola, [18]. The diffuse, stunted, and eroded secondary lamellae of the gills coupled with severe congestion of the blood channel at the core of the primary lamellae reported in this study were in line with previous findings of Nowak, [28], Neskovic et al., [29] and Ayoola, [18]. The presence of severe diffuse vacuolation of the hepatocytes, moderate to severe portal congestion, and mild diffuse vacuolation of hepatocytes in the liver samples were similar to the report of Ayoola, [18] where he reported that the most frequent types of degenerative changes encountered are hydropic degeneration, cloudy swelling, vacuolization, and focal necrosis. Risbourg and Bastide, [30] also reported an increase in the size of lipid droplets and vacuolization in the liver of fish exposed to atrazine herbicide. At the highest treatment dose of $0.3 \mathrm{mls}$, there was moderate diffuse vacuolation of hepatocytes and severe portal congestion. In the present study, the kidney of Clarias gariepinus exposed to Force-Up showed mild to moderate congestion of the interstitium and focus of interstitial oedema within the parenchyma. These lesions were similar to the reports of Oulmi et al., [31], Omoniyi et al., [23], Rahman et al., [24].

Fish and aquatic invertebrates have been considered to be an excellent model for studying the toxic, mutagenic and carcinogenic potential of the water pollutants $[32,33]$ as they play different roles in the trophic web such as undergoing bio-accumulation of environmental pollutants, biotransformation of 
xenobiotics through cytochrome P450-dependent oxidative metabolism and respond to mutagens at low concentration. The presence of micronucleus formation in the fish nucleated red blood cells at higher treatment $(0.225 \mathrm{mls}$ and $0.3 \mathrm{mls})$ concentrations in this study is also in support of a previous study carried out by Nwani et al., [34] which reported micronucleus formation in erythrocytes of $C$. punctatus after exposure to carbosulfan $\left(0.07,0.13\right.$ and $\left.0.20 \mathrm{mg} \mathrm{L}^{1}\right)$, glyphosate $\left(8.1,16.3\right.$ and $\left.24.4 \mathrm{mg} \mathrm{L}^{1}\right)$ and atrazine $\left(10.6,21.2\right.$ and $\left.31.8 \mathrm{mg} \mathrm{L}^{1}\right)$ for 96 hours.

\section{Conclusion}

Glyphosate is used extensively in aquaculture, and it's the world's most used herbicide. The results and the available information on glyphosate toxicity and its formulations on different groups of cultured catfish in this study revealed that they are menacing and unsafe to the aquatic environment, and cause histopathological changes in different organs especially, at higher concentrations and particularly, in livers, kidneys, and gills.

Despite the benefits derived from the use of glyphosate-based herbicides, the result of this work, like many others, portends that herbicides can potentially harm the aquatic environment, human health and can even alter the world food chain cycle. Glyphosate residue could reach humans and animals through feed consumption and contact with or use of contaminated water. Unknown impacts of glyphosate on human and animal health warrant further investigations of glyphosate residues in vertebrates and other non-target organisms). Finally, the study has therefore established that glyphosate-based herbicides are toxic to Clarias gariepinus (African Catfish) at high concentrations.

Farmers should also be discouraged not to use high concentrations of herbicides around fish ponds. Most of the world's population depends on fish as another major alternative to a protein source, then the agricultural and aquaculture communities should therefore be conscious of the potential adverse effects of this pesticide and several others. To protect the water quality and safety of aquatic animals, Government should therefore enact policies that will guide against the use of dangerous herbicides in the control of terrestrial and aquatic weeds. Also, farming activities should not be too close to water bodies especially, farms that rely on chemical control of weeds. This is to prevent the water body from the residue of herbicides that would have washed down to the water.

\section{Declarations}

\section{Acknowledgements}

Not applicable

\section{Author Contributions}

OKA shared efforts in conceptualization and study design, supervision, review and editing of the manuscript. SAS shared efforts in conceptualization, study design and implementation, data analyses 
and interpretation, supervision, writing, review and editing of the manuscript. EOA assisted with study implementation, data collection. All authors read and approved the final manuscript.

\section{Ethics approval and consent to participate}

The University of Ibadan Animal Care and Use in Research Committee (UI-ACUREC) approved this study's protocol and all procedures with an assigned number UI-ACUREC/019-0220/6.

The research survey was both online and offline with negligible risk and only non-identifiable data were used. Eligible participants were not vulnerable subjects, no greater than minimal risks of informational and psychological harms. Participants were assured of anonymity and confidentiality prior to their participation and were given the right to refuse to take part in the survey. Participants who gave consent to willingly participate in the online survey would click the 'Continue' button and would then be directed to complete the self-administered questionnaire while willing physical respondents signed the consent forms.

\section{Consent for publication}

Not applicable

\section{Availability of data and materials}

The datasets during and/or analysed during the current study available from the corresponding author on reasonable request.

\section{Competing interests}

The authors declare that they have no competing interests

\section{References}

1. Delince G. The ecology of the fish pond ecosystem with special reference to Africa. Netherland, Kluwer Academic Publishers 1999; 191-196.

2. Ifejika PI, Ayanda JO, Sule AM. Socioeconomic variables affecting aquaculture production practices in Borgu local government area of Niger State, Nigeria. Journal of aquaculture and social research (JASR) 2007; 7(2): 20-29.

3. Dedeke GA, Owagboriaye FO, Ademolu KO, Olujimi, OO, Aladesida AA. Comparative Assessment on Mechanism Underlying Renal Toxicity of Commercial Formulation of Roundup Herbicide and Glyphosate Alone in Male Albino Rat. International Journal of Toxicology 2018; 1-11. DOI: 10.1177/1091581818779553.

4. Alarape SA, Ajani F, Adeyemo OK, Shobiye, JO. Effect of Copper Sulphate on Spawning Success in African Catfish (Clarias gariepinus, Burchell 1822), Journal of Fisheries and Aquatic Science 2013; Vol. 8 (6): 714-720. DOI: 10.3923/jfas.2013.714.720 
5. Adeyemo OK, Alarape SA, Emikpe BO. Reprotoxic Effect of Malachite Green on African Catfish Clarias gariepinus (Burchell 1822), Journal of Fisheries and Aquatic Science 2011; 6 (5): 1-8. DOI: 10.3923/jfas.2011.563.570

6. Benbrook CM. Trends in glyphosate herbicide use in the United States and globally. Environ Sci Europe 2016; 28:3.

7. Acquavella JF, Alexander BH, Mandel JS, Gustin C, Baker B, Champan P, Bleeke M. Glyphosate biomonitoring for farmers and their families: results from the farm family exposure study. Environ. Health Perspect. 2004; 112, 321-326.

8. USDA. Herbicide Background Statement: Glyphosate. In: Pesticide Background Statements. Vol 1: Herbicides USDA Forest Service, Agricultural Handbook No 633: G-1-72. 1984.

9. Li J, Smeda RJ, Sellers BA, Johnson WJ. Influence of formulation and glyphosate salt on absorptionand translocation in three annual weeds. Weed Science 2005; 53:153-159. DOI: 10.1614/WS-03-075R1.

10. Krüger M, Schrödl W, Neuhaus J, Shehata AA. Field Investigations of Glyphosate in Urine of Danish Dairy Cows. J Environ Anal Toxicol 2013; 3 (5): 100-186.

11. IFEN. Report on pesticides in waters 2007. Data 2005

12. Clive J. Global status of biotech/GM Crops: 2008. ISAAA 2009; Brief 39.

13. Gasnier C, Dumont C, Benachour N, Clair E, Chagnon MC, Séralini GE. Glyphosate-based herbicides are toxic and endocrine disruptors in human cell lines. Toxico/ 2009; 262:184-191.

14. Alishahi M, TulabyDezfuly Z, Mohammadian T. Acute toxicity evaluation of five herbicides: paraquat, 2,4-dichlorophenoxy acetic acid (2,4-D), trifluralin, glyphosite and atrazine in Luciobarbusesocinusfingerlings. Iranian Journal of Veterinary Medicine 2016; 10 (4): 319-330.

15. Jatinder PKG, Nidhi S, Anand M, Shivika D, Madhuri G. Glyphosate toxicity for animals. Environmental chemistry letters 2017; 16 (2): 401-426.

16. Monsanto International and Monsanto Europe. The agronomic benefits of glyphosate in Europebenefits of glyphosate per market use. Review 2010; 1-82

17. WHO (World Health Organisation). Glyphosate. Environmental Health Criteria 159. The Internal Programme on Chemical Safety (IPCS), WHO, Geneva. Cited in: Buffin, D., Jewell, T. (2001). Health and Environmental Impact of Glyphosate: The Implications of Increased use of Glyphosate in Association with Genetically Modified Crops. In: Riley, P., Taylor, M., Diamand, E., Barron, H., (Eds.). UK 1994; $1-40$.

18. Ayoola SO. Toxicity of glyphosate herbicide on Nile tilapia (Oreochromis niloticus) juvenile. African Journal of Agricultural Research 2008; 3(12): 825-834.

19. Gill JPK, Sethi N, Mohan A. Analysis of the glyphosate herbicide in water, soil and food using derivatising agents. Environ. Chem. Lett. 2017;15: 85-100. doi: 10.1007/s10311-016-0585-z.

20. Neibor E, Richardson DH. Replacement of non-descript term heavy metal by a biological and chemically significant classification of metal ions. Environmental Pollution Series 1980; 3(1): 34-41. 
21. Valavanidis A. Glyphosate, the Most Widely Used Herbicide. Health and safety issues. Why scientists differ in their evaluation of its adverse health effects. Department of Chemistry, National and Kapodistrian University of Athens, University Campus Zografou 2018; 15784 Athens. www.chem-toxecotox.org/ScientificReviews.

22. Aguigwo JN. The toxic effect of cymbush pesticide on growth and survival of African catfish, Clarias gariepinus (BURCHELL1822). J. Aquat. Sci., 2002; 17(2): 81-84.

23. Omoniyi IA, Agbon O, Sodunke SA. Effects of lethal and sub-lethal concentrations of tobacco (Nicotiana tobaccum), leaf dust extracted on weight, and haematological changes in Clarias gariepinus (Buchell 1822) J. Applied Sc. Environ.Man. 2002; 6: 37-41.

24. Rahman MZ, Hossain Z, Mellah MFR, Ahmed GU. Effect of Dia zinon 60EC on Anabus testudineus, Channa punctatus and Barbades gomonotus. NAGA. The ICLARM Quarterly 2002; 25: 8-11.

25. Okayi RG, Annune PA, Tachia MU, Oshoke OJ. Acute toxicity of glyphosate on Clarius gariepinus fingerlings, J. Res. For. Wildl. Environ 2010; 2 (2).

26. Sani A, Idris MK. Acute toxicity of herbicide (glyphosate) in Clarias gariepinus juveniles. Toxicology Reports 2016; 3: 513-515. http://dx.doi.org/10.1016/j.toxrep.2016.05.004

27. Fryer JD. Weed Control Handbook Vol.1 Edited by Make Peace 1977; 384-389.

28. Nowak B. Histological changes in gills induced by residues of endosulfan. Aquat Toxicoll.1992; 23: 63-84.

29. Neskovic NK, Poleksic V, Elezovic I, Karan V, Budimir M. Biochemical and histopathological effects of glyphosate on Carp. (Cyprinus carpio. L) Bull Environ contam Toxicol.1996; 56: 295-302.

30. Risbourg SB, Bastide J. Hepatic perturbations induced by a herbicide (atrazine) in juvenile grey mullet Liza ramada (Mugilidae Telostei): an ultra-structural study. Aquat Toxicol.1995; 31: 217-29

31. Oulmi Y, Negele RD, Braunbeck T. Cytopathology of liver and kidney in rainbow trout (Oncorhynchus mykiss) after long-term exposure to sublethal concentrations of linuron. Dis. Aquat. Org. 1995; 21: 35-52.

32. Kumar R, Nagpure NS, Kushwaha B, Srivastava SK, Lakra WS. Investigation of the genotoxicity of malathion to freshwater teleost fish Channa punctatus (Bloch) using the micronucleus test and comet assay. Arch. Environ. Contam Toxicol. 2010; 58, 123-130.

33. Osman A, Mekkawy I, Verreth J, Wuertz S, Kloas W, Kirschbaum F. Monitoring of DNA breakage in embryonic stages of the African catfish Clarias gariepinus (Burchell, 1822) after exposure to lead nitrate using alkaline comet assay. Environ. Toxicol. 2008; 23: 679-687.

34. Nwani CD, Nagpure NS, Kumar R, Kushwaha B, Kumar P, Lakra WS. Induction of micronuclei and nuclear lesions in Channa punctatus following exposure to carbosulfan, glyphosate, and atrazine. Drug Chem Toxicol, 2013; Early Online: 1-8.

\section{Figures}




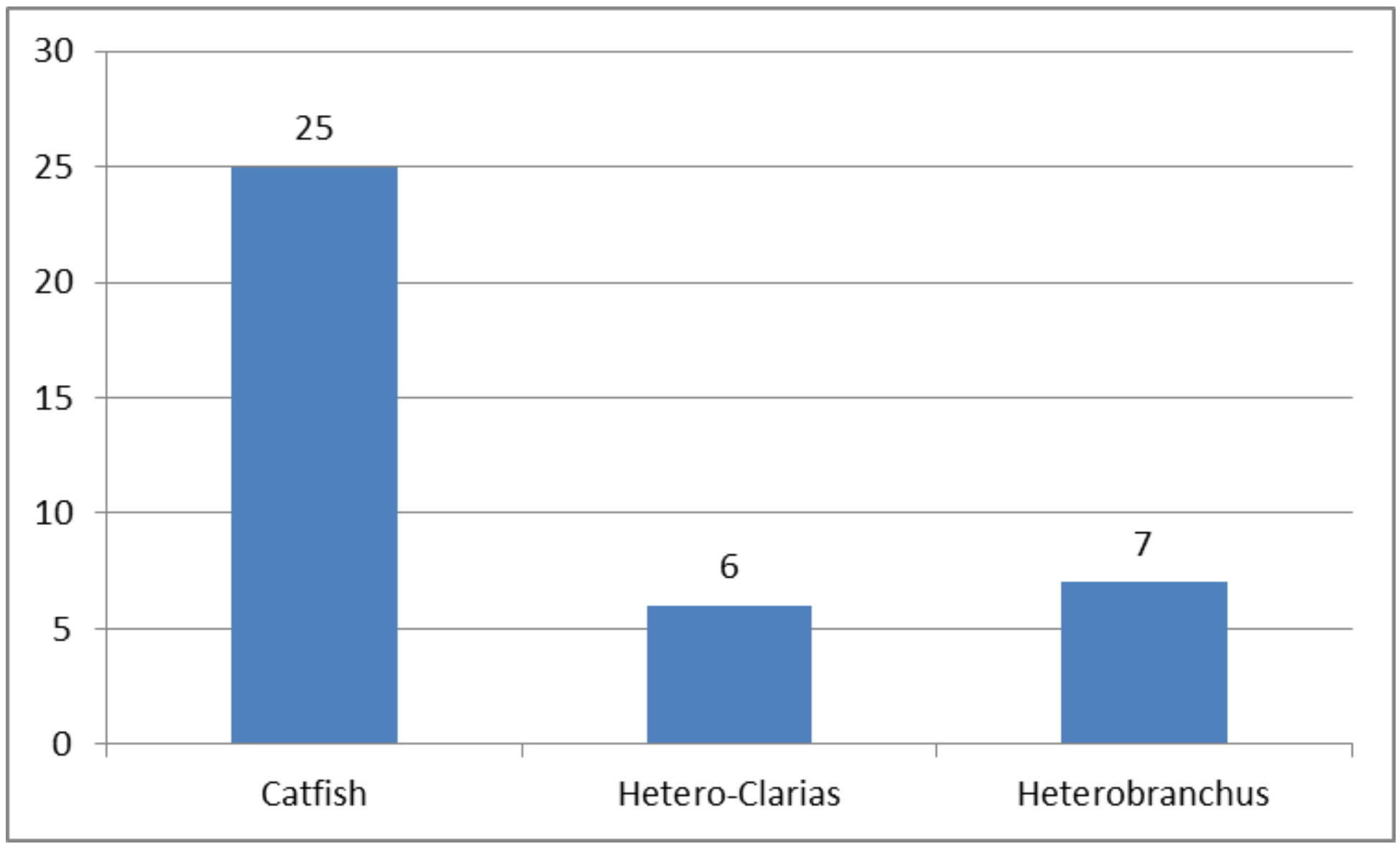

Figure 1

showing Distribution of Cultured Fish 


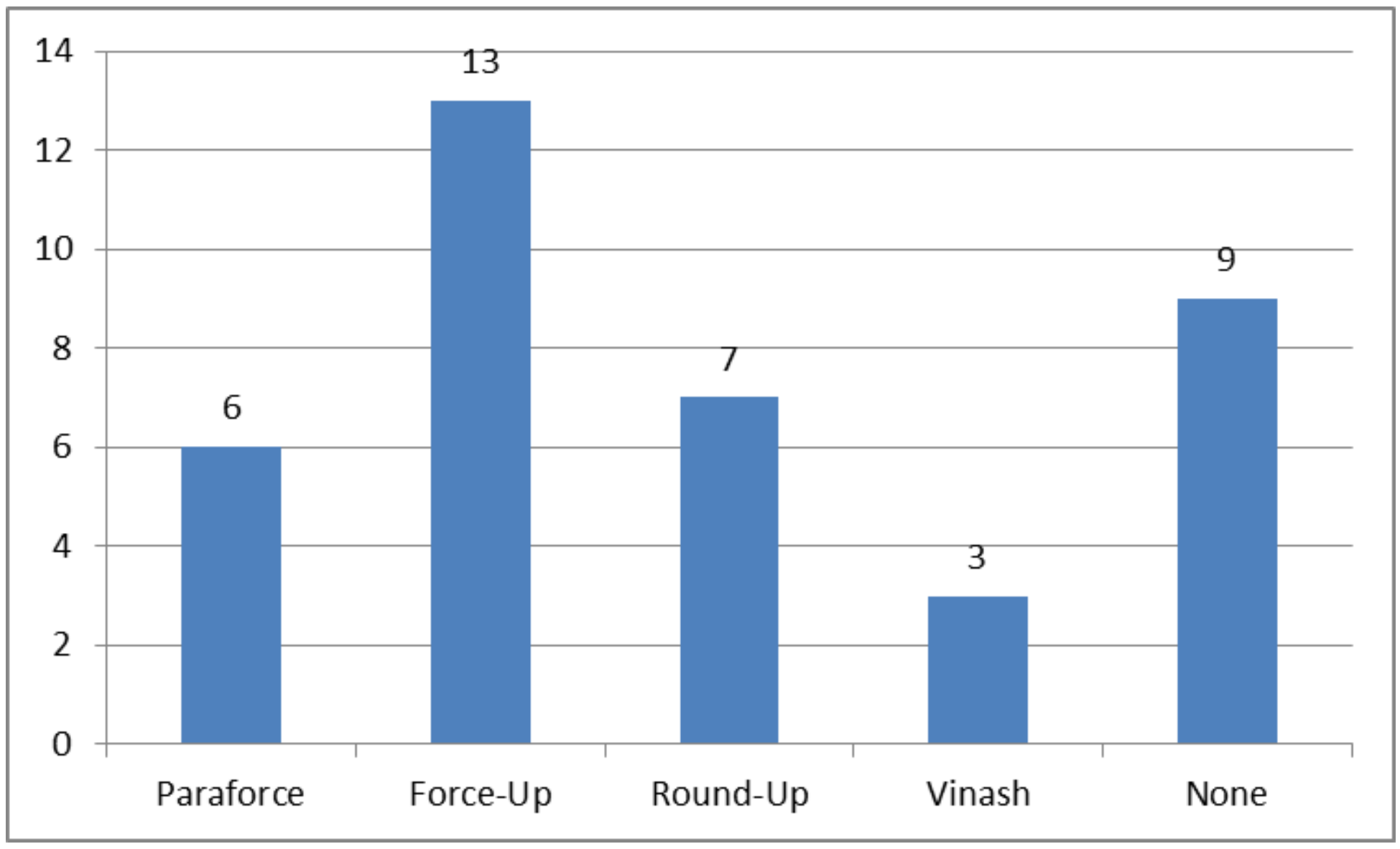

Figure 2

showing Distribution of Glyphosate-based Herbicides use in Fish Farms 


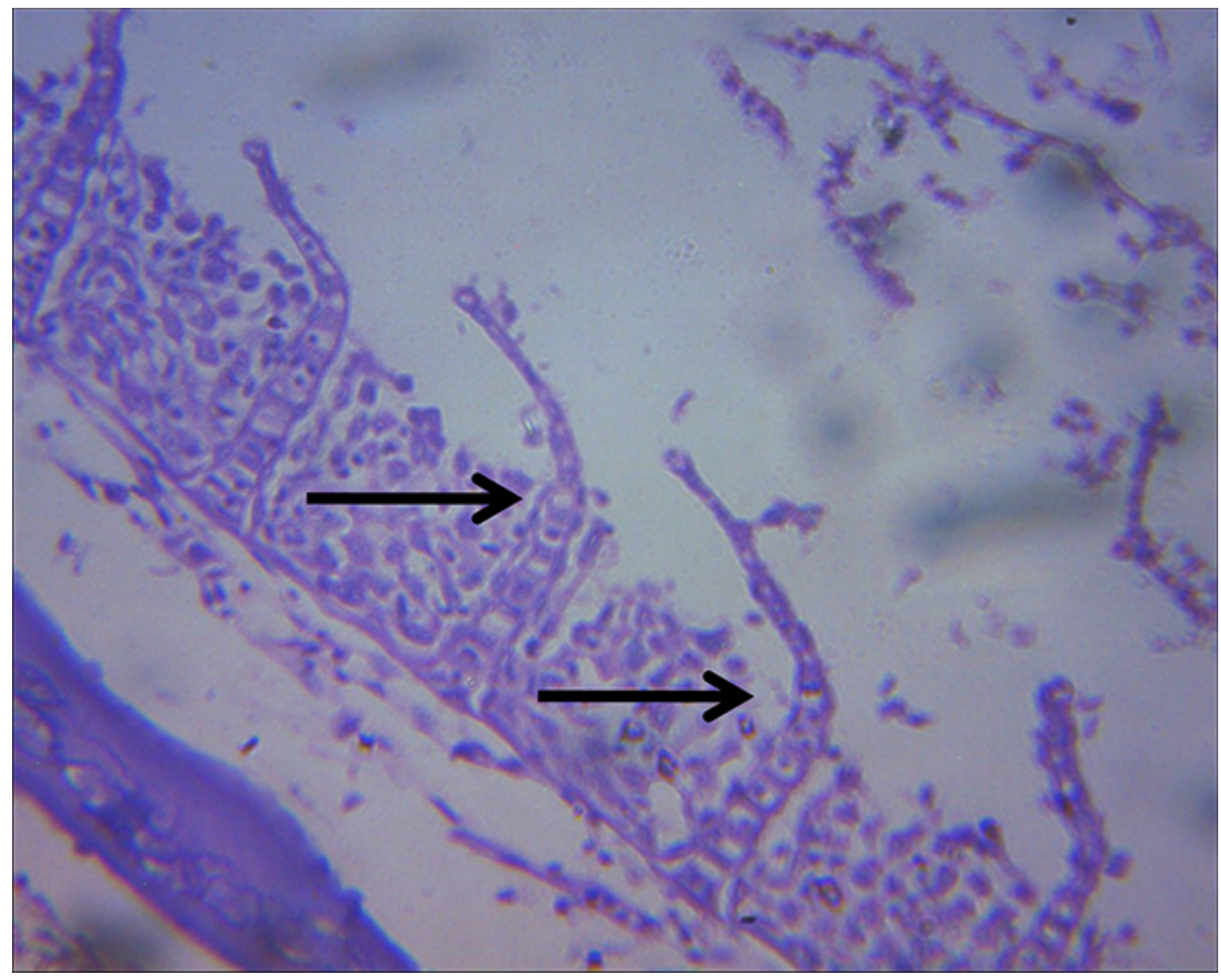

\section{Figure 3}

Diffusely Stunted and Eroded Secondary Lamellae of the Gills (Arrows) at First treatment concentration $(0.15 \mathrm{mls})$ 


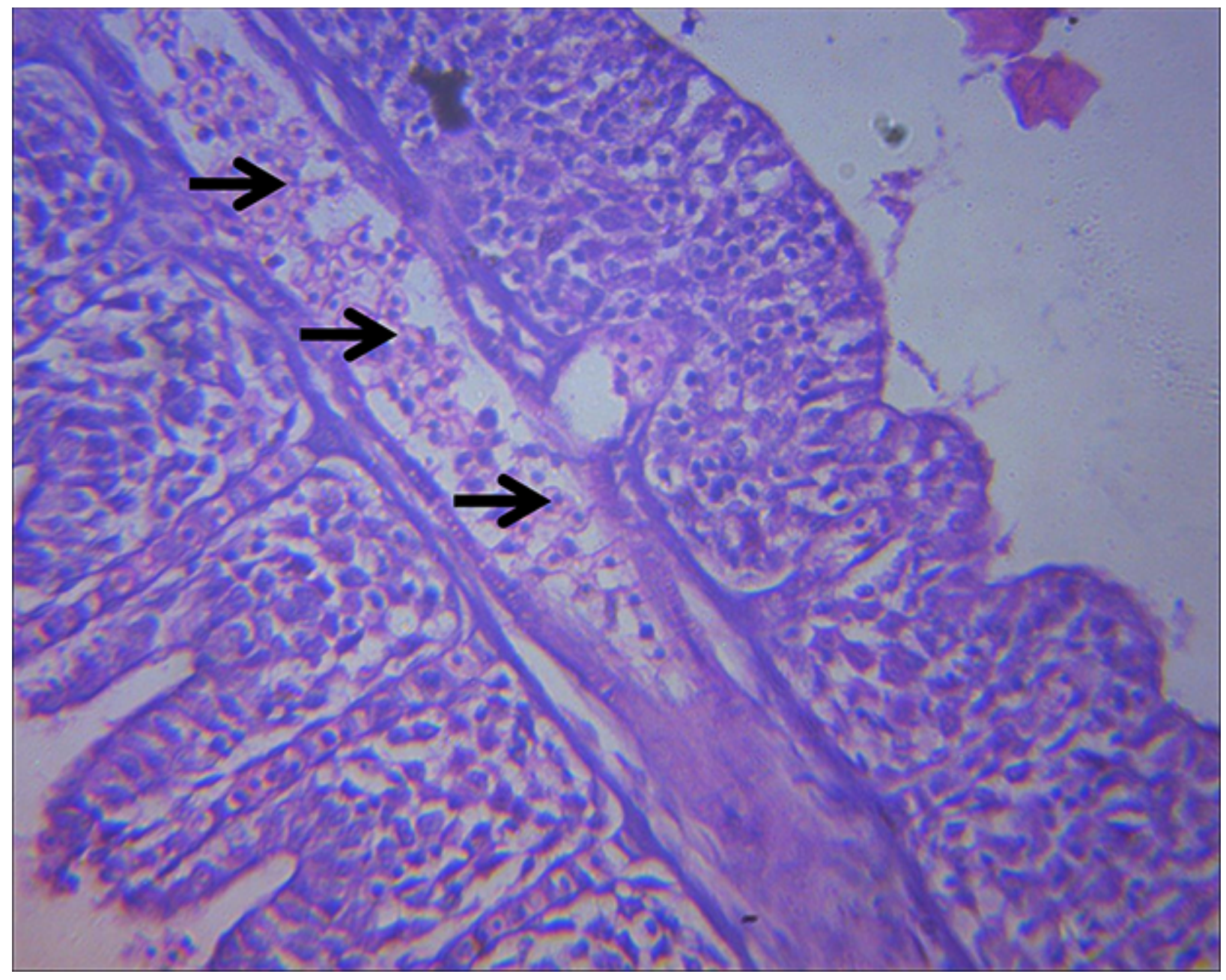

Figure 4

Severe Congestion of the Blood Channel at the Core of the Primary Lamellae (arrows) at second treatment concentration $(0.225 \mathrm{mls})$ 


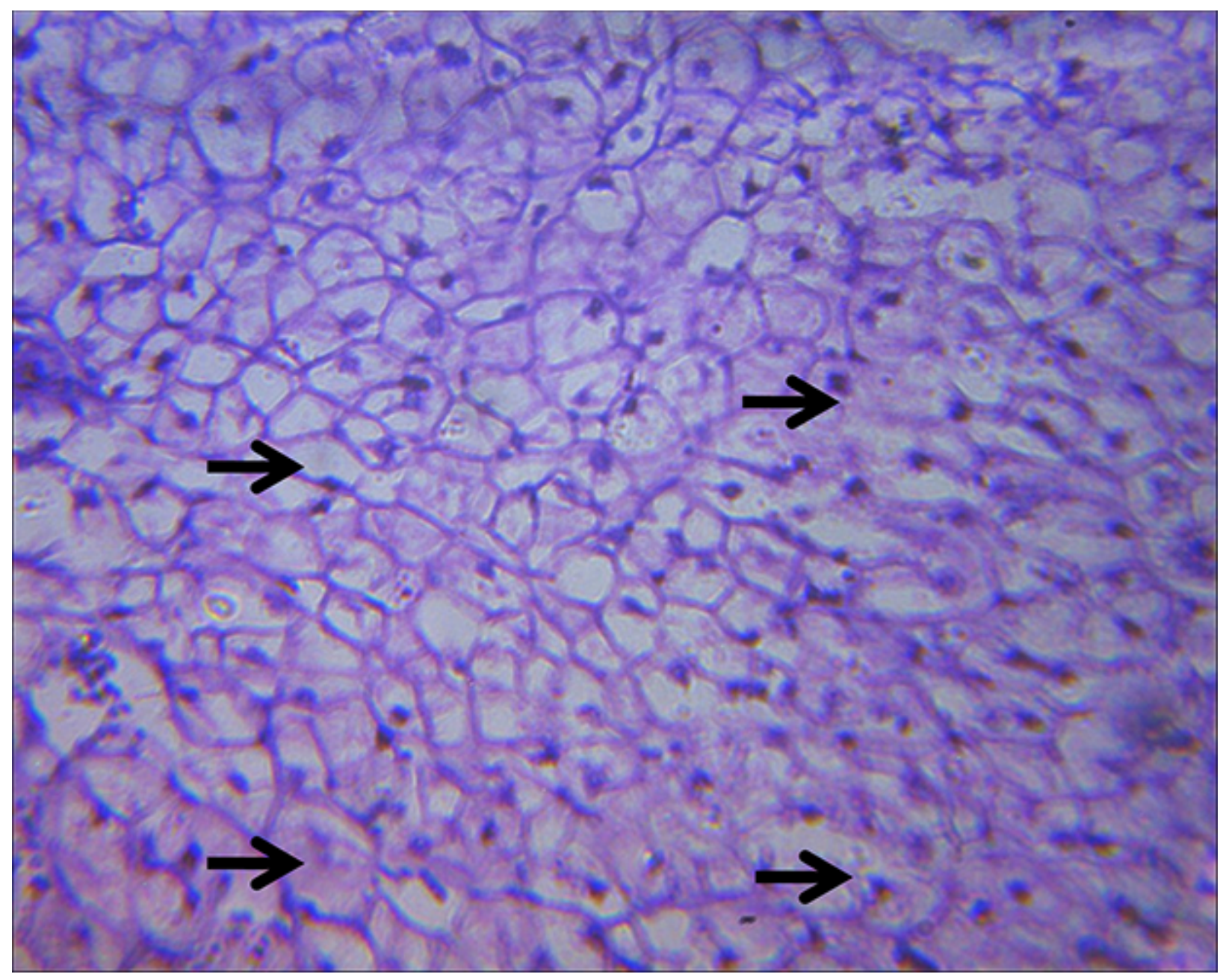

\section{Figure 5}

Severe Diffuse Vacuolation of the Hepatocytes (Arrows) at First Treatment Concentration $(0.15 \mathrm{mls})$ 


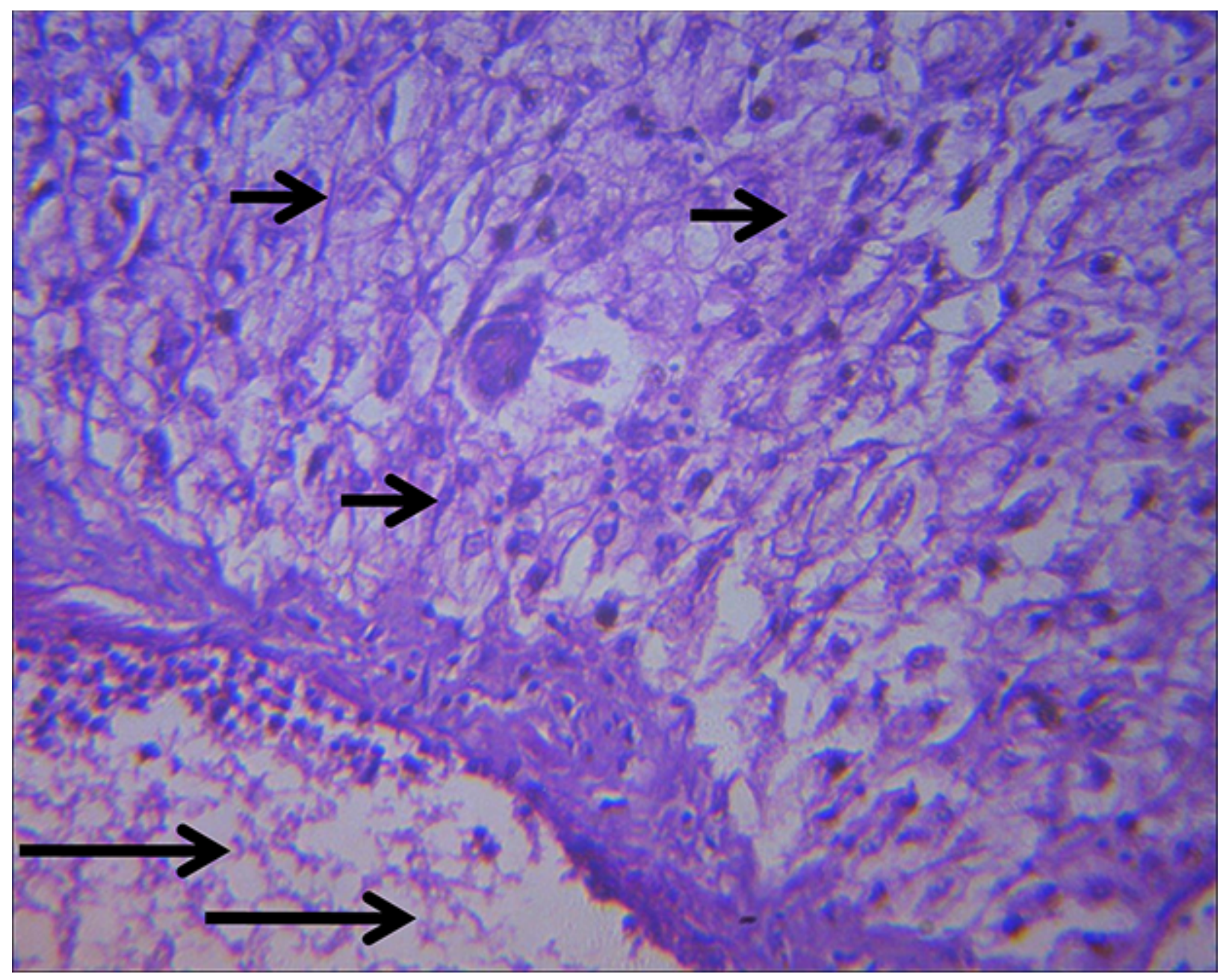

\section{Figure 6}

Moderate to Severe Portal Congestion (long arrows) and Mild Diffuse Vacuolation of Hepatocytes (short arrows) at Second Treatment Concentration $(0.225 \mathrm{mls})$ 


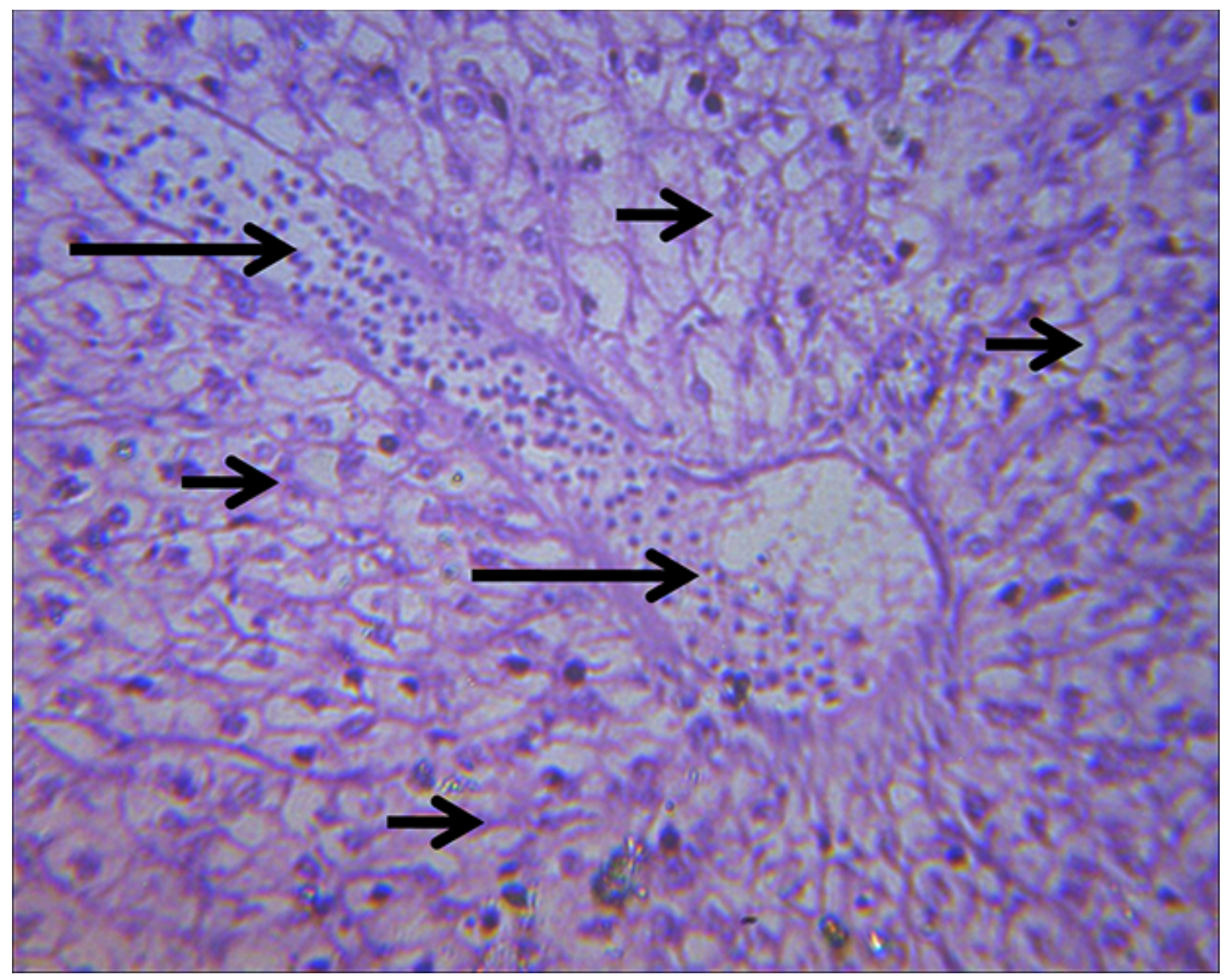

\section{Figure 7}

Moderate Diffuse Vacuolation of Hepatocytes and Severe Portal Congestion at Third Treatment Concentration $(0.3 \mathrm{mls})$ 


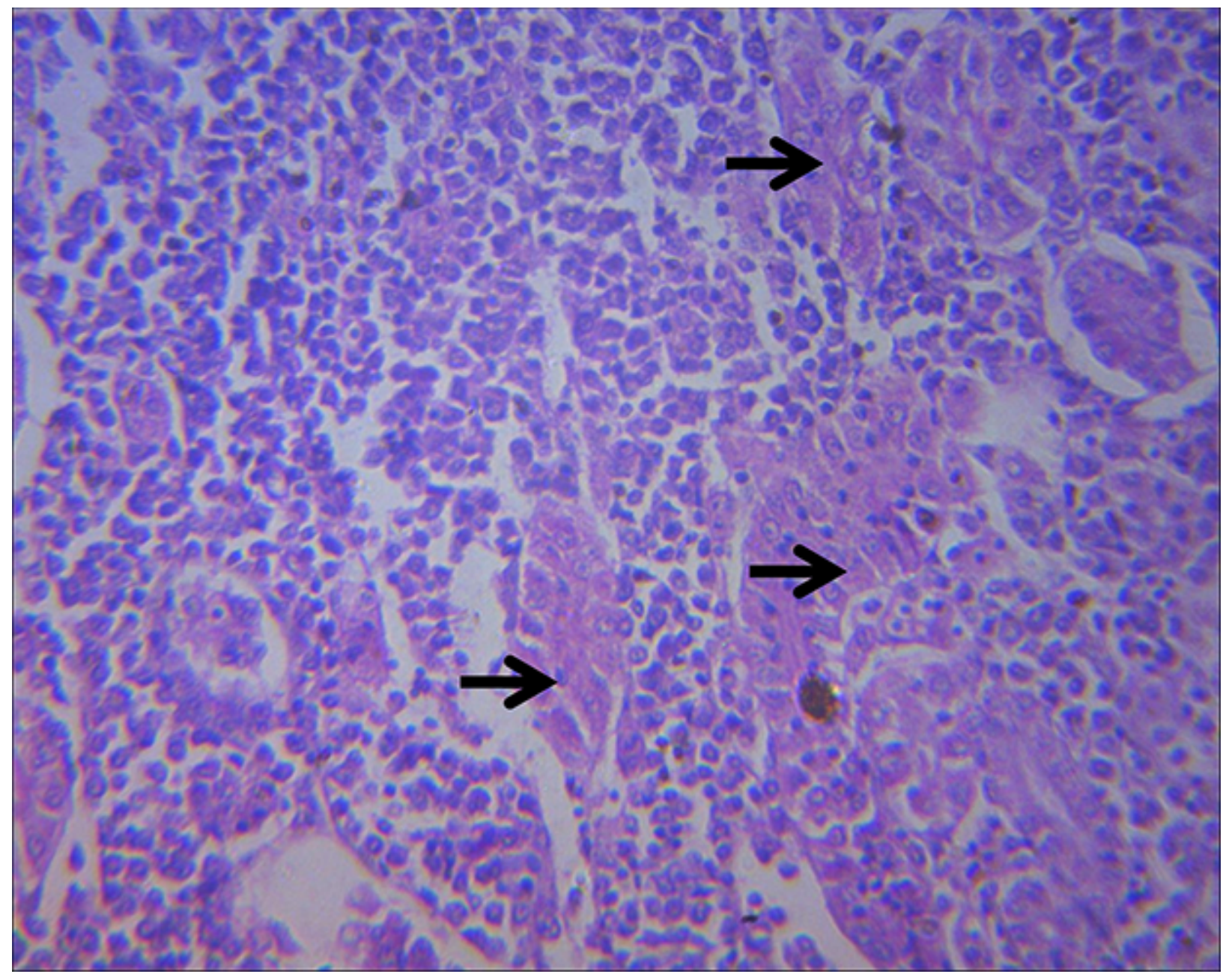

Figure 8

Mild to Moderate Congestion of the Interstitium at Second Treatment Concentration $(0.225 \mathrm{mls})$ 


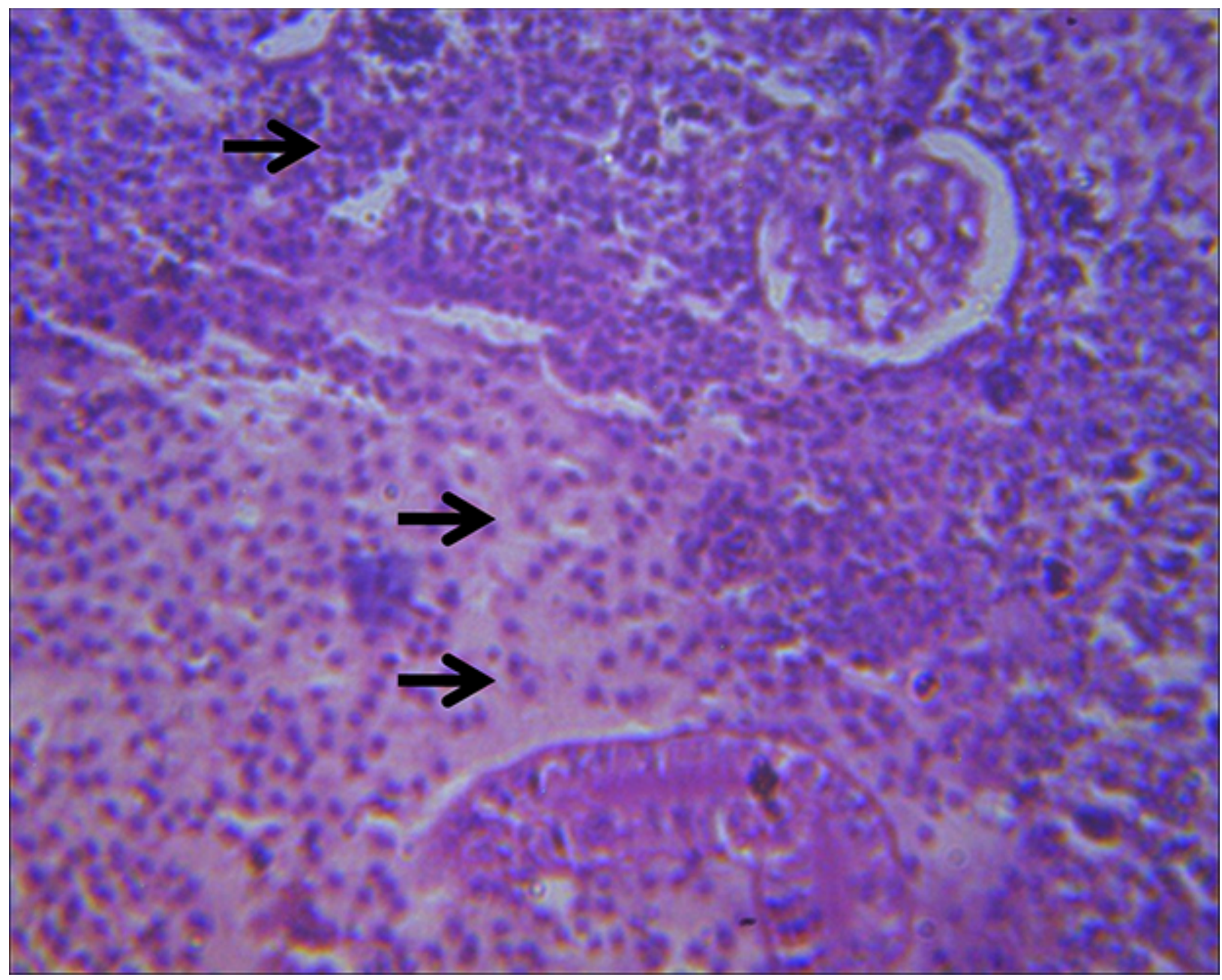

\section{Figure 9}

Focus of Interstitial Oedema within the Parenchyma at Third Treatment Concentration $(0.3 \mathrm{mls})$ 


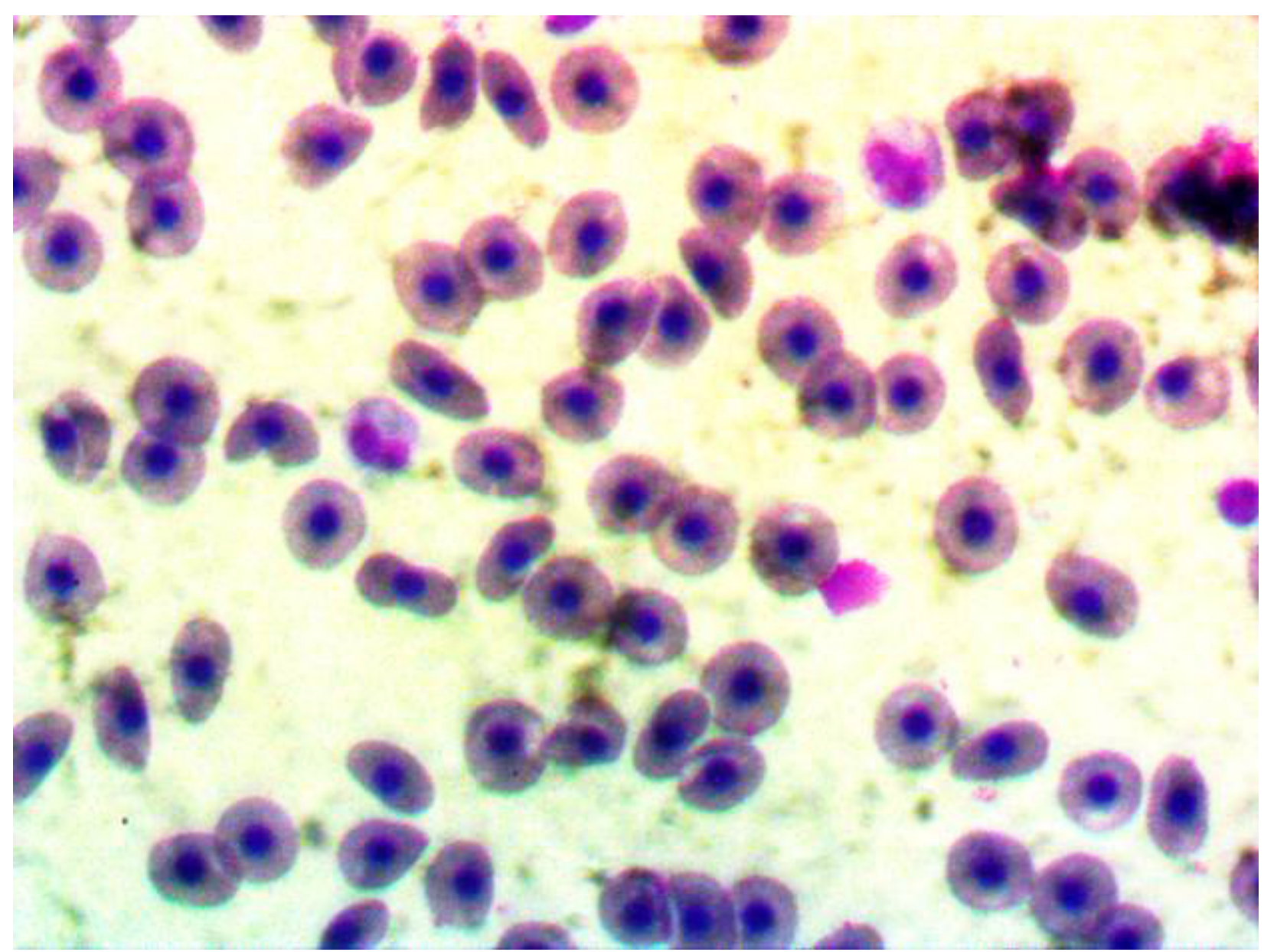

Figure 10

Photomicrograph showing Normal Fish Nucleated Red Blood Cell (Giemsa x1000) 


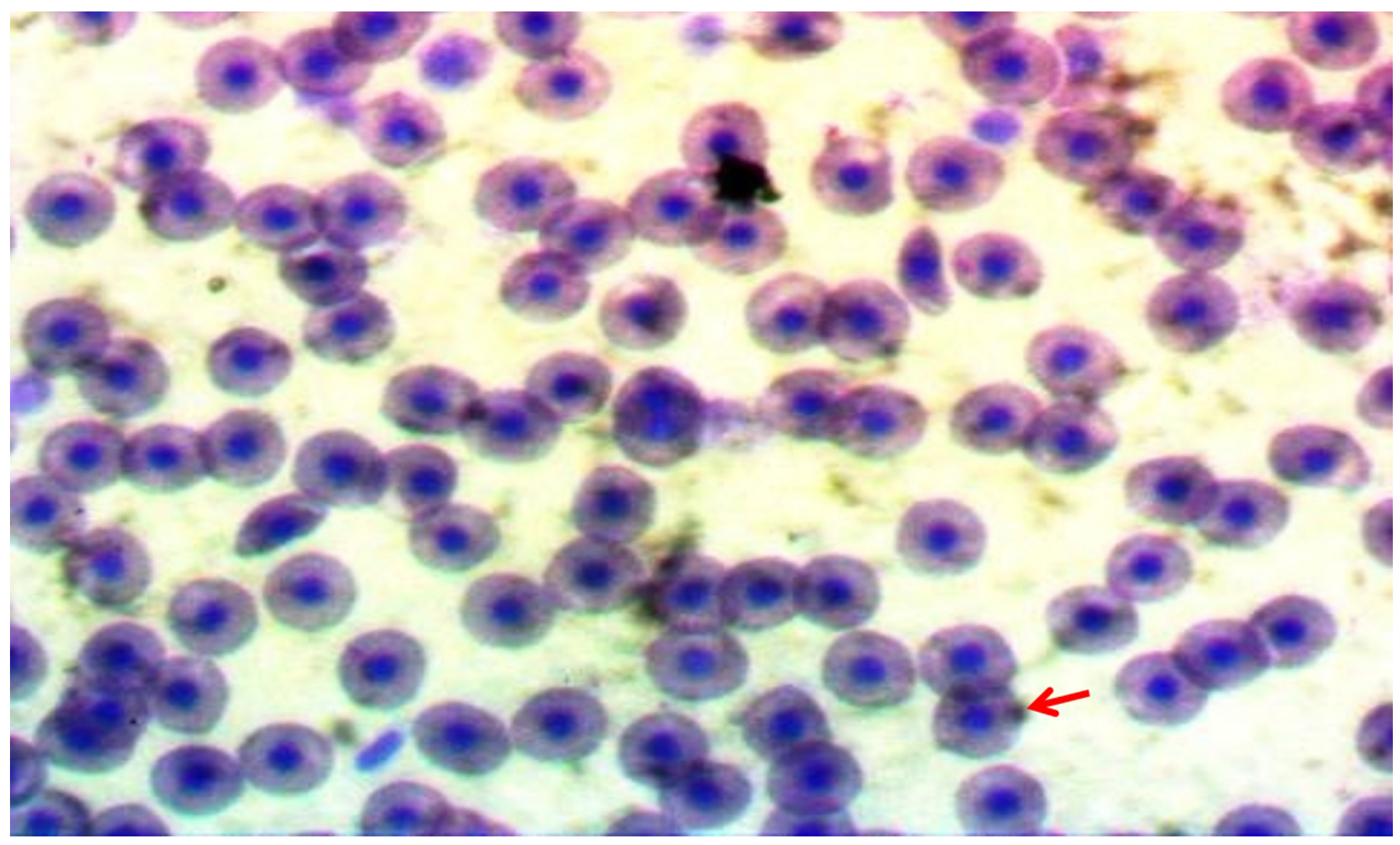

Figure 11

Photomicrograph showing Micronucleus (red arrow) in the Fish Nucleated Red Blood cell at $0.225 \mathrm{ml}$ Treatment Concentration (Giemsa x1000) 


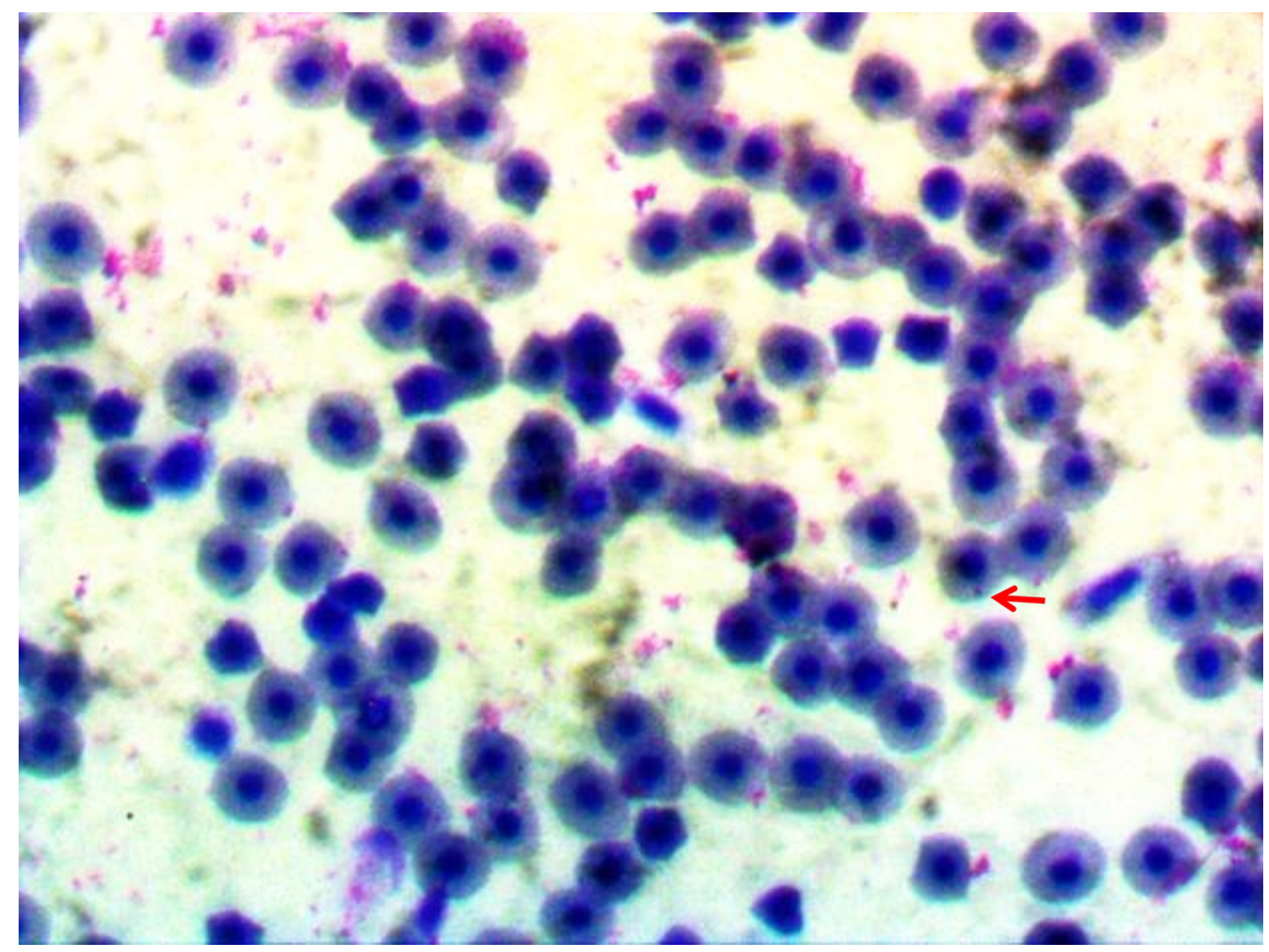

Figure 12

Photomicrograph showing Micronucleus (red arrow) in the Fish Nucleated Red Blood Cell at 0.3mls Treatment Concentration (Giemsa x1000)

\section{Supplementary Files}

This is a list of supplementary files associated with this preprint. Click to download.

- GlyphosateResidueQuestionnaire.doc 